\title{
Appendix A: Maps showing all the Idaho Department of Fish and Game properties under the Albeni Falls Wildlife Mitigation Project
}

Figure 1. Idaho Department of Fish and Game: Boundary Creek Wildlife Management Area.

Figure 2. Idaho Department of Fish and Game: Smith Creek Wildlife Management

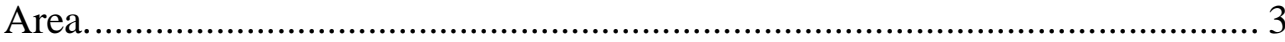

Figure 3: Idaho Department of Fish and Game: Deep Creek Habitat Segment. Boundary Creek and the Northern Wildlife Management Areas.

Figure 4. Idaho Department of Fish and Game: Albeni Cove Habitat Segment. Pend Oreille Wildlife Management Area.

Figure 5. Idaho Department of Fish and Game: Carter's Island Habitat Segment. Pend Oreille Wildlife Management Area.

Figure 6: Idaho Department of Fish and Game: Cocolalla Lake Habitat Segment. Pend Oreille Wildlife Management Area.

Figure 7. Idaho Department of Fish and Game: Denton Slough Habitat Segment. Pend Oreille Wildlife Management Area. ............................................................ 8

Figure 8. Idaho Department of Fish and Game: Derr Creek Habitat Segment. Pend Oreille Wildlife Management Area.

Figure 9: Idaho Department of Fish and Game: Gold Creek Habitat Segment. Pend Oreille Wildlife Management Area.

Figure 10. Idaho Department of Fish and Game: Lower Pack River Habitat Segment. Pend Oreille Wildlife Management Area.

Figure 11. Idaho Department of Fish and Game: Rapid Lightning Creek Habitat Segment. Pend Oreille Wildlife Management Area.

Figure 12. Idaho Department of Fish and Game: Trout Creek Habitat Segment. Pend Oreille Wildlife Management Area.

Figure 13. Idaho Department of Fish and Game: Westmond Lake Habitat Segment.

Pend Oreille Wildlife Management Area.

Figure 14. Idaho Department of Fish and Game: Lower St. Joe Habitat Segment. Coeur d'Alene Wildlife Management Area. 
Figure 1. Idaho Department of Fish and Game: Boundary Creek Wildlife Management Area.
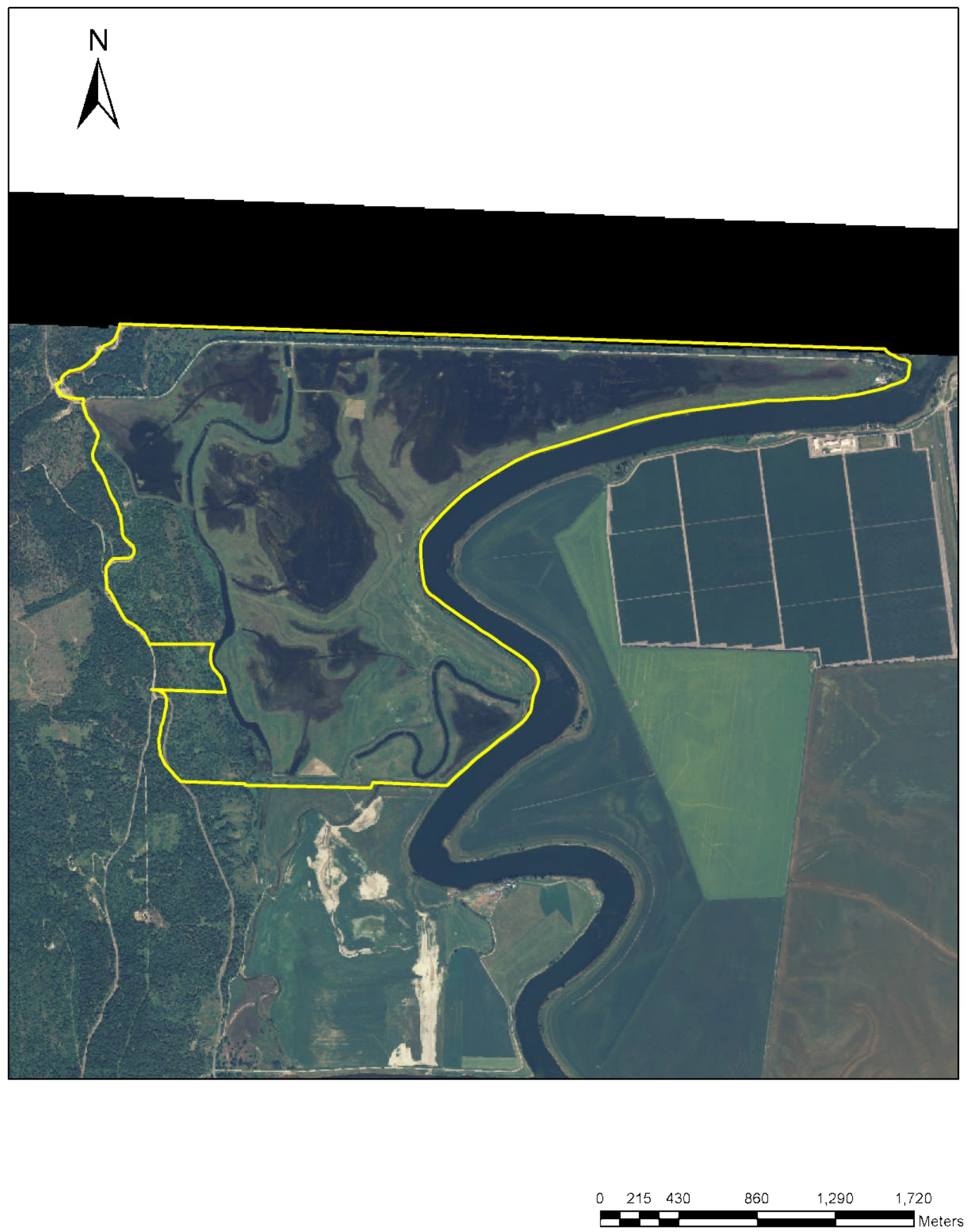
Figure 2. Idaho Department of Fish and Game: Smith Creek Wildlife Management Area.

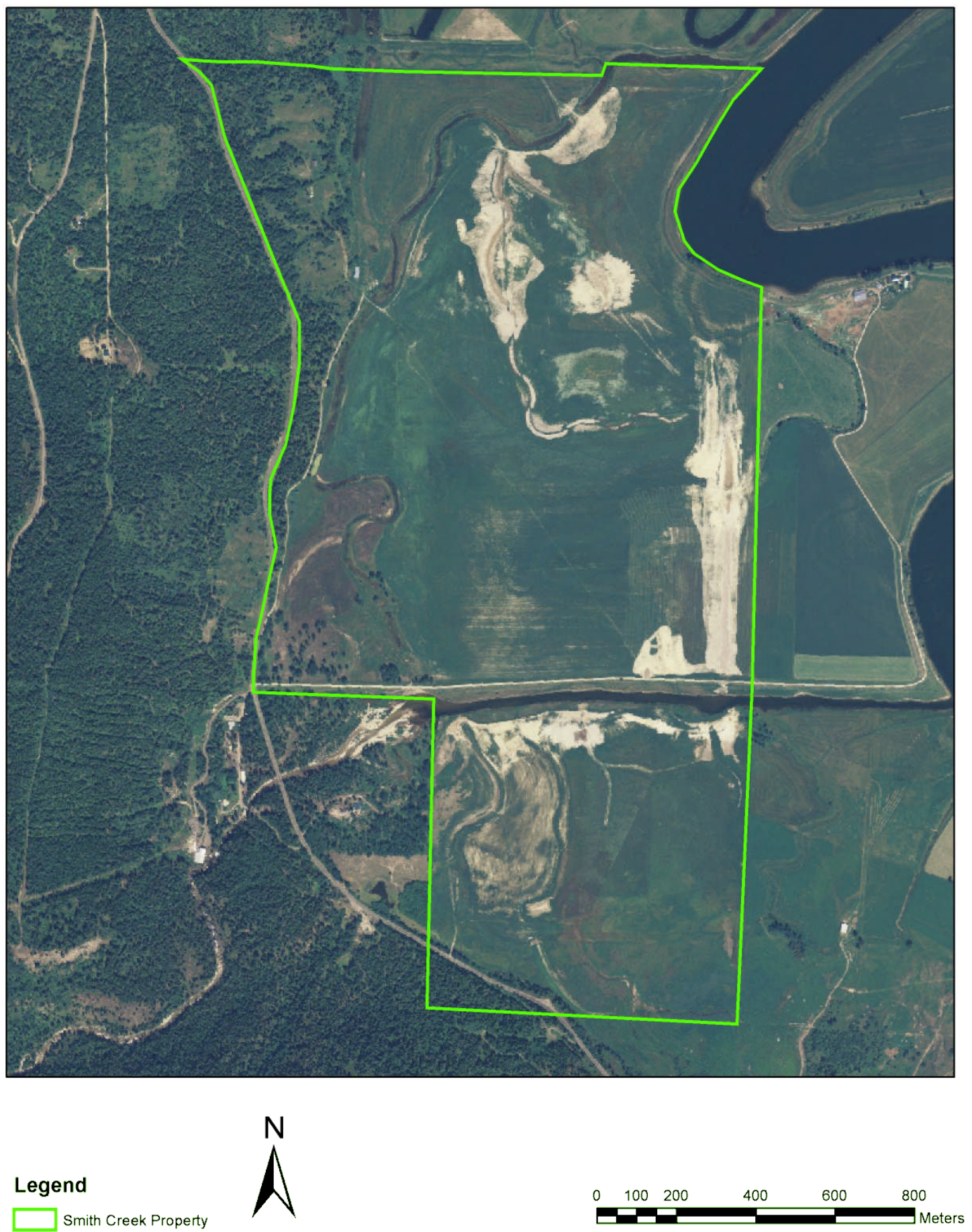


Figure 3: Idaho Department of Fish and Game: Deep Creek Habitat Segment. Boundary Creek and the Northern Wildlife Management Areas.

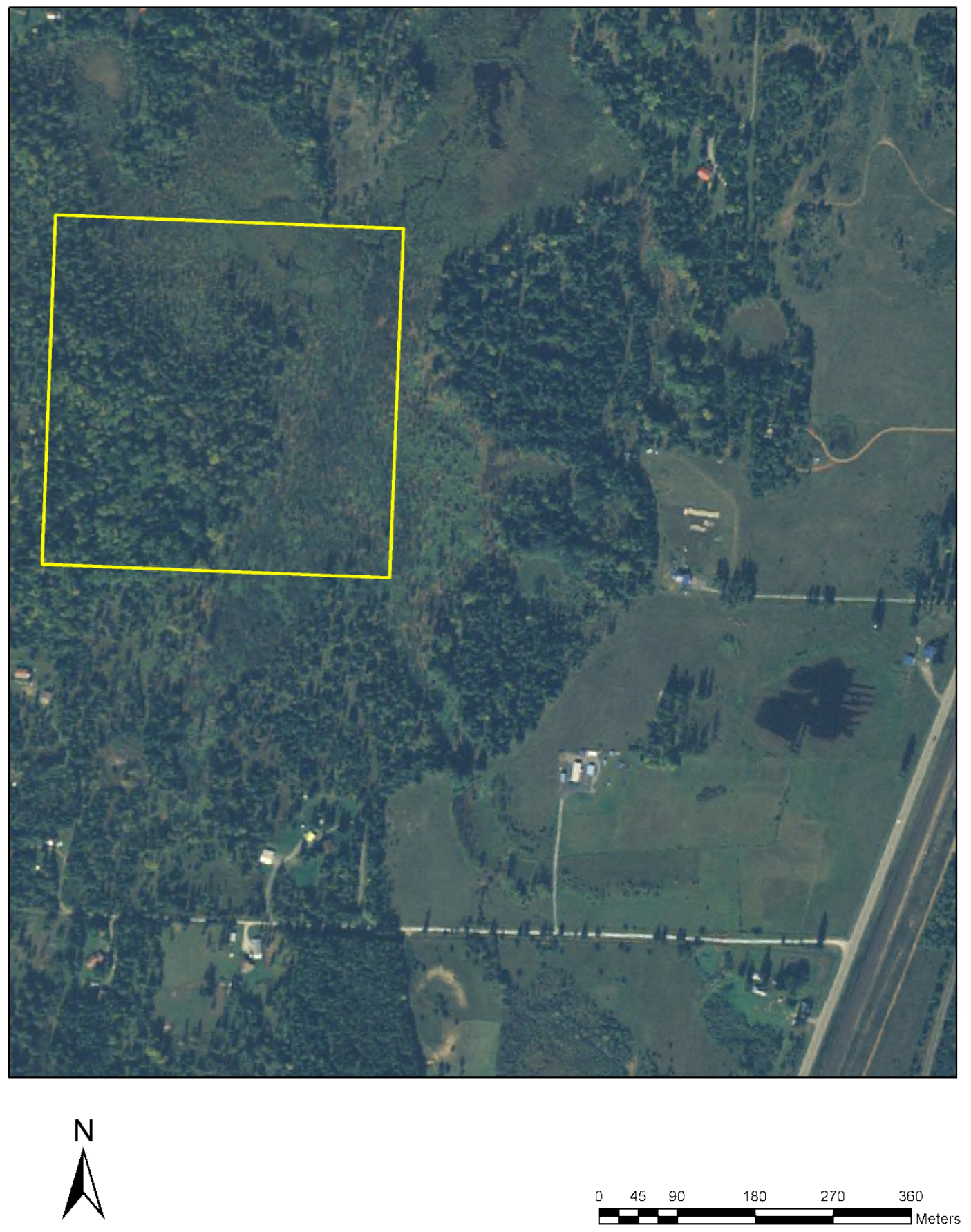


Figure 4. Idaho Department of Fish and Game: Albeni Cove Habitat Segment. Pend Oreille Wildlife Management Area.

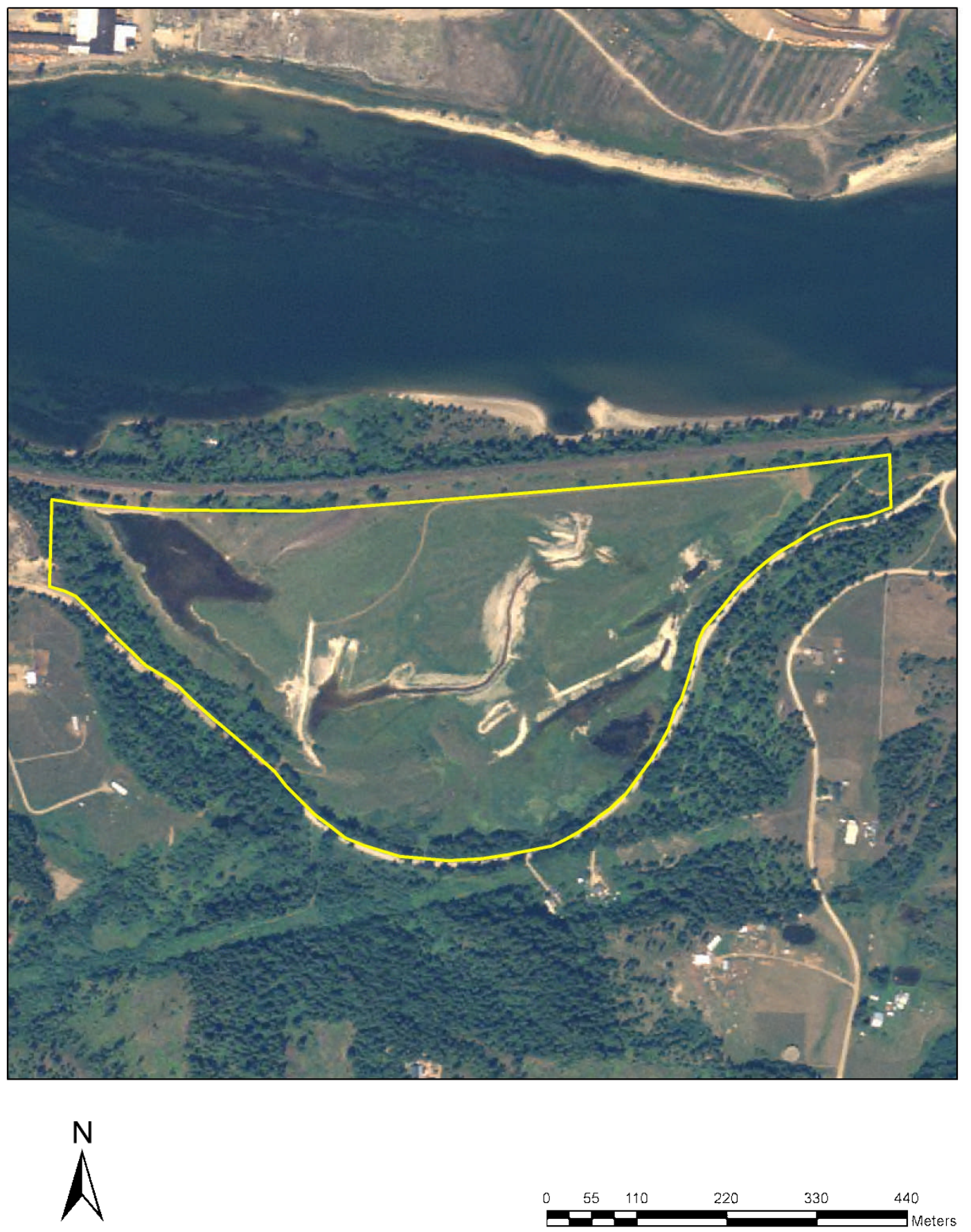


Figure 5. Idaho Department of Fish and Game: Carter's Island Habitat Segment. Pend Oreille Wildlife Management Area.

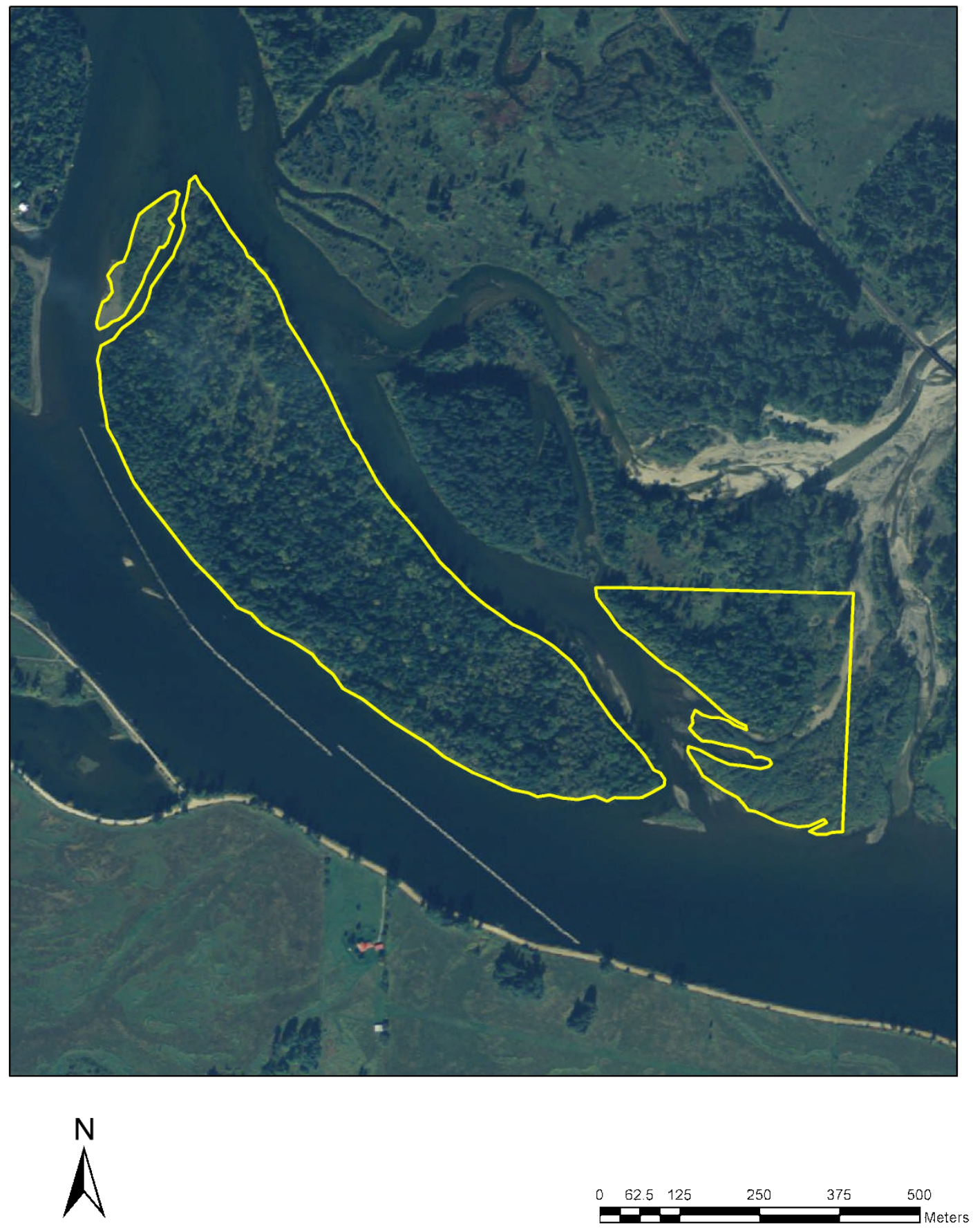


Figure 6: Idaho Department of Fish and Game: Cocolalla Lake Habitat Segment. Pend Oreille Wildlife Management Area.

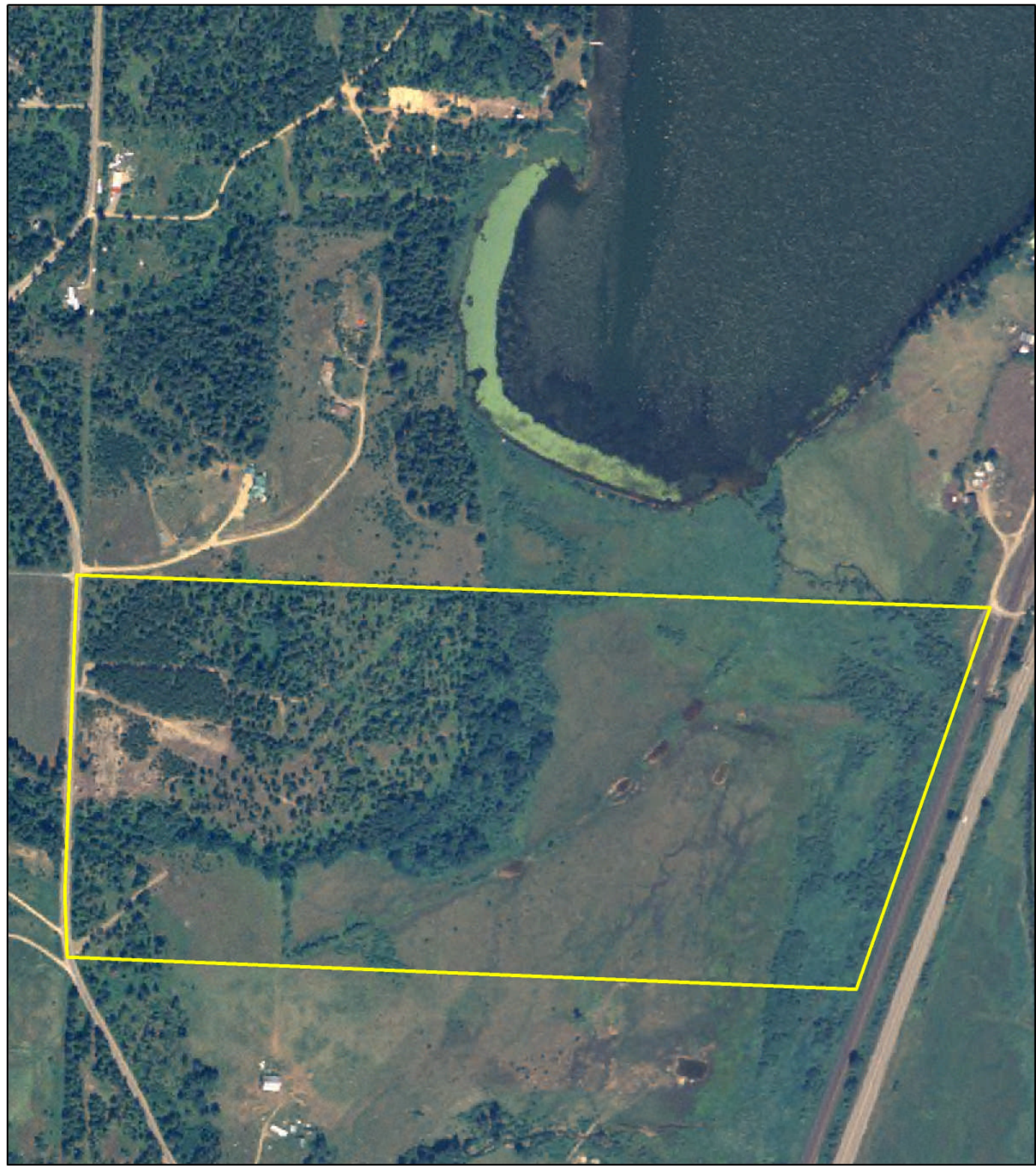

$\mathrm{N}$
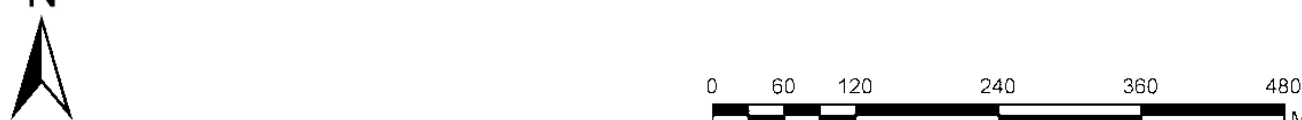

Meters 
Figure 7. Idaho Department of Fish and Game: Denton Slough Habitat Segment. Pend Oreille Wildlife Management Area.

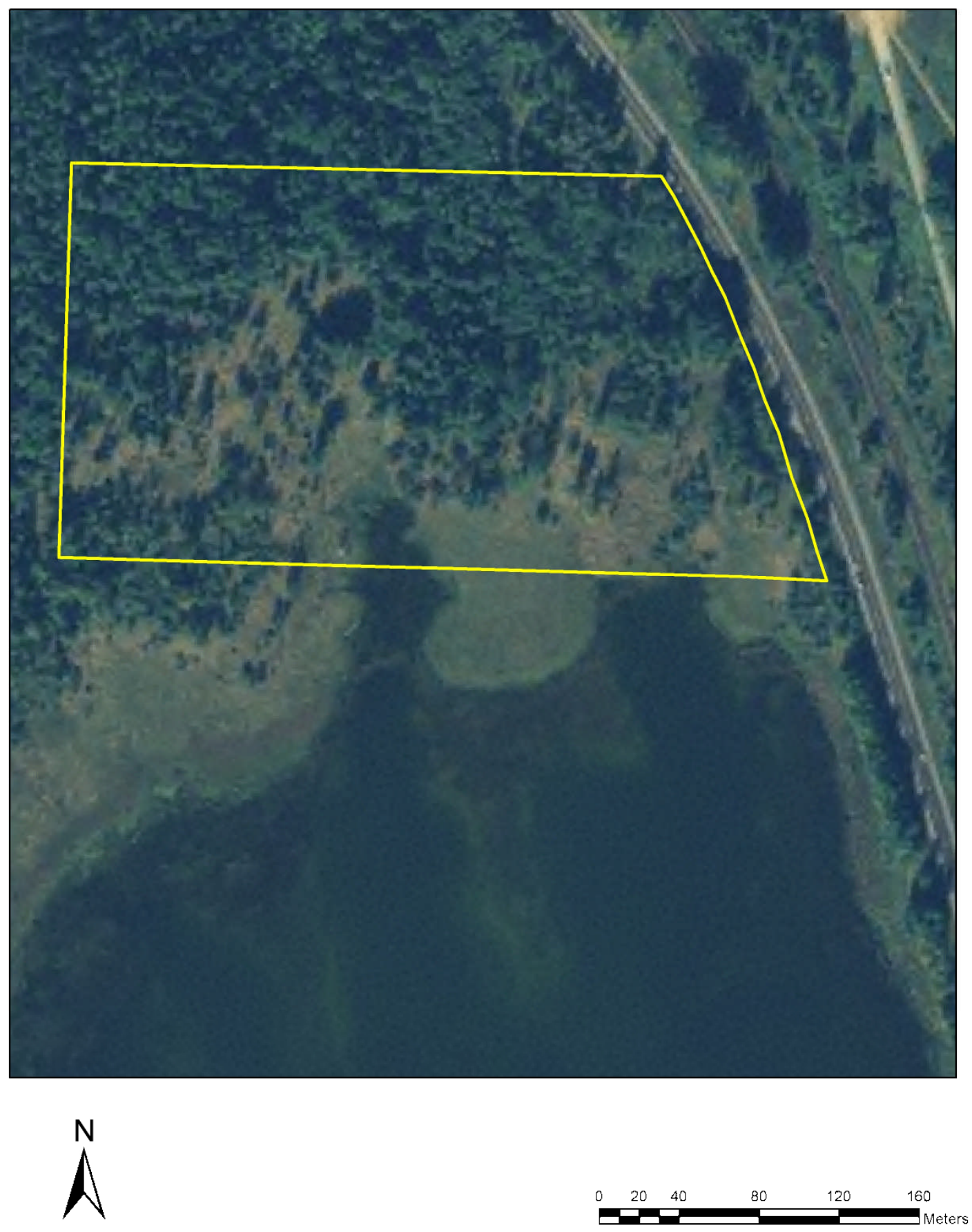


Figure 8. Idaho Department of Fish and Game: Derr Creek Habitat Segment. Pend Oreille Wildlife Management Area.

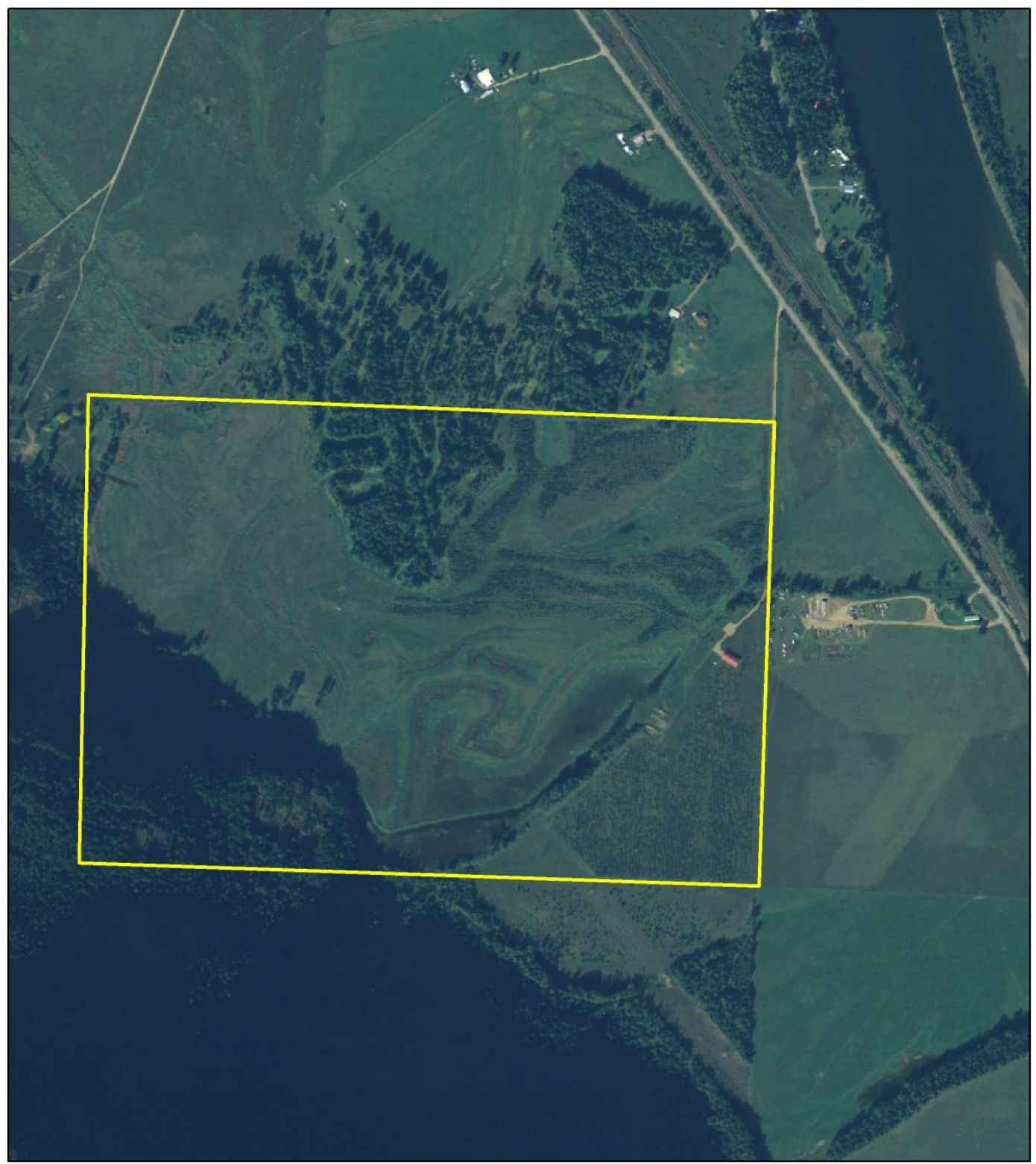

$\mathrm{N}$
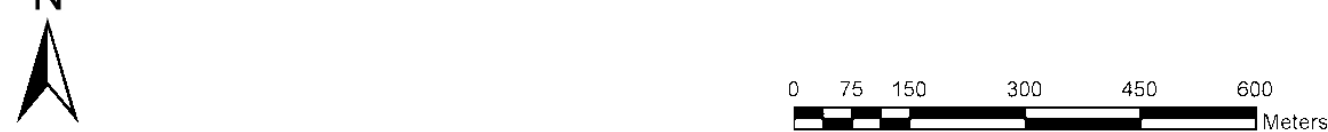
Figure 9: Idaho Department of Fish and Game: Gold Creek Habitat Segment. Pend Oreille Wildlife Management Area.

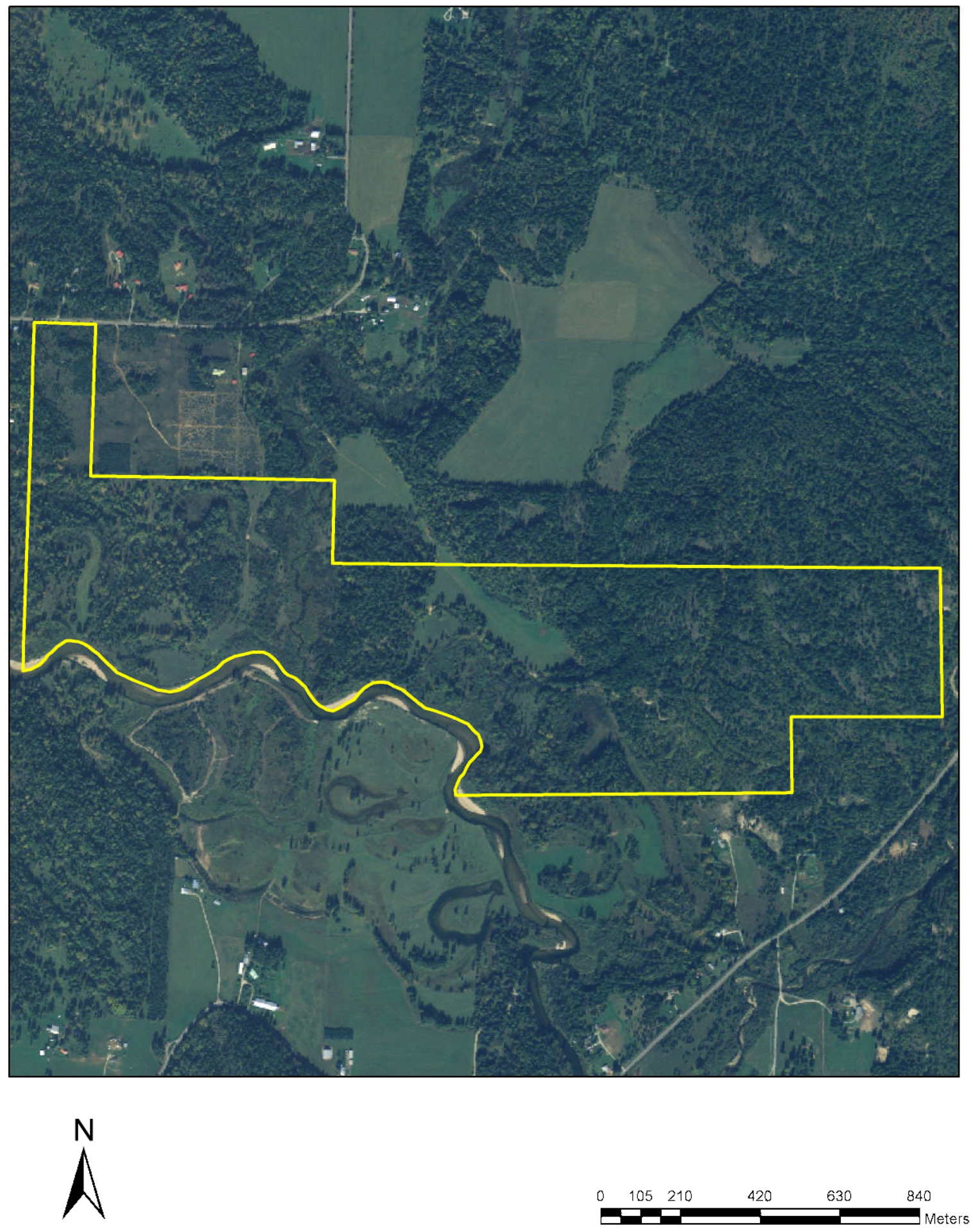


Figure 10. Idaho Department of Fish and Game: Lower Pack River Habitat Segment. Pend Oreille Wildlife Management Area.

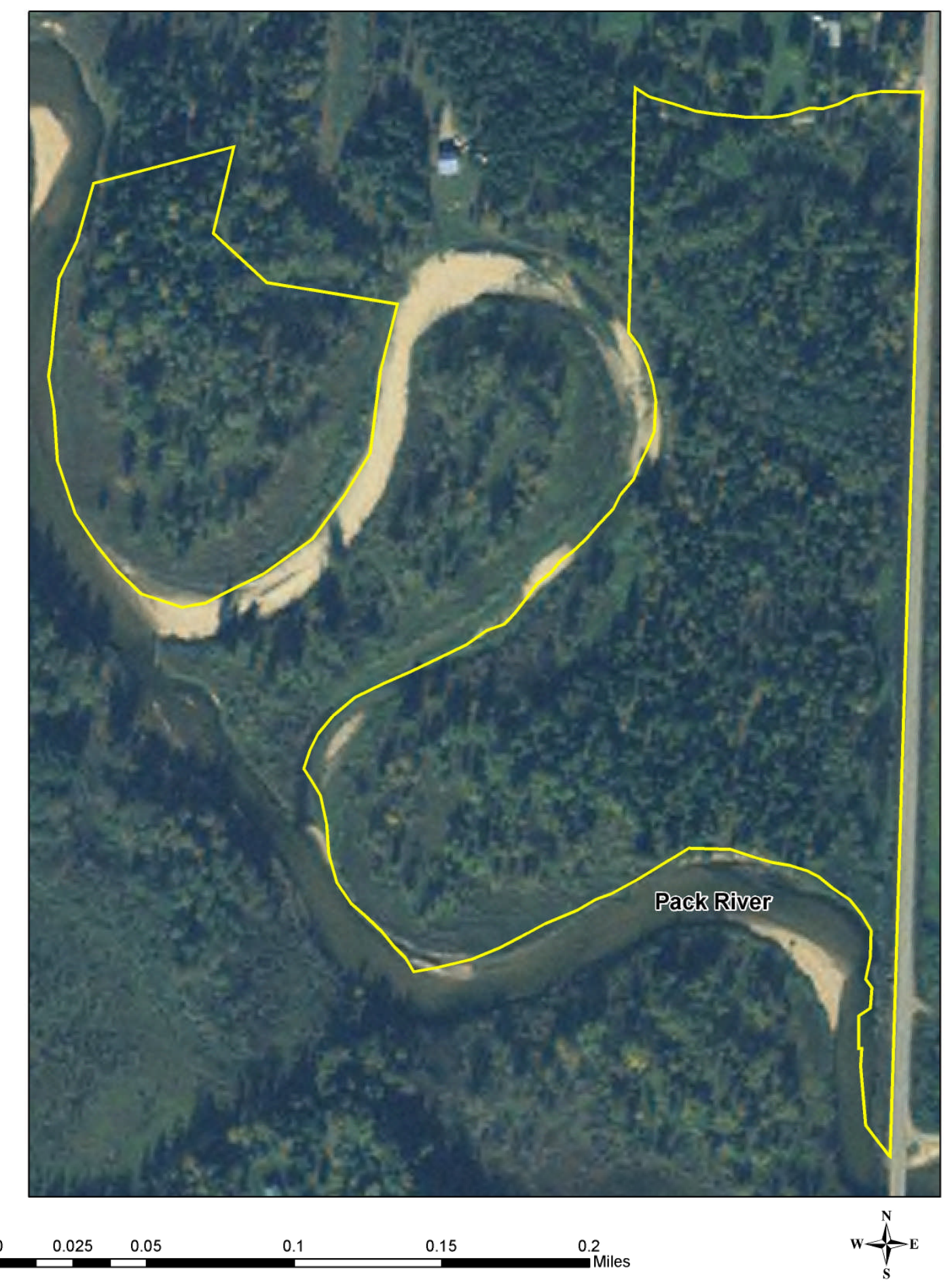


Figure 11. Idaho Department of Fish and Game: Rapid Lightning Creek Habitat Segment. Pend Oreille Wildlife Management Area.
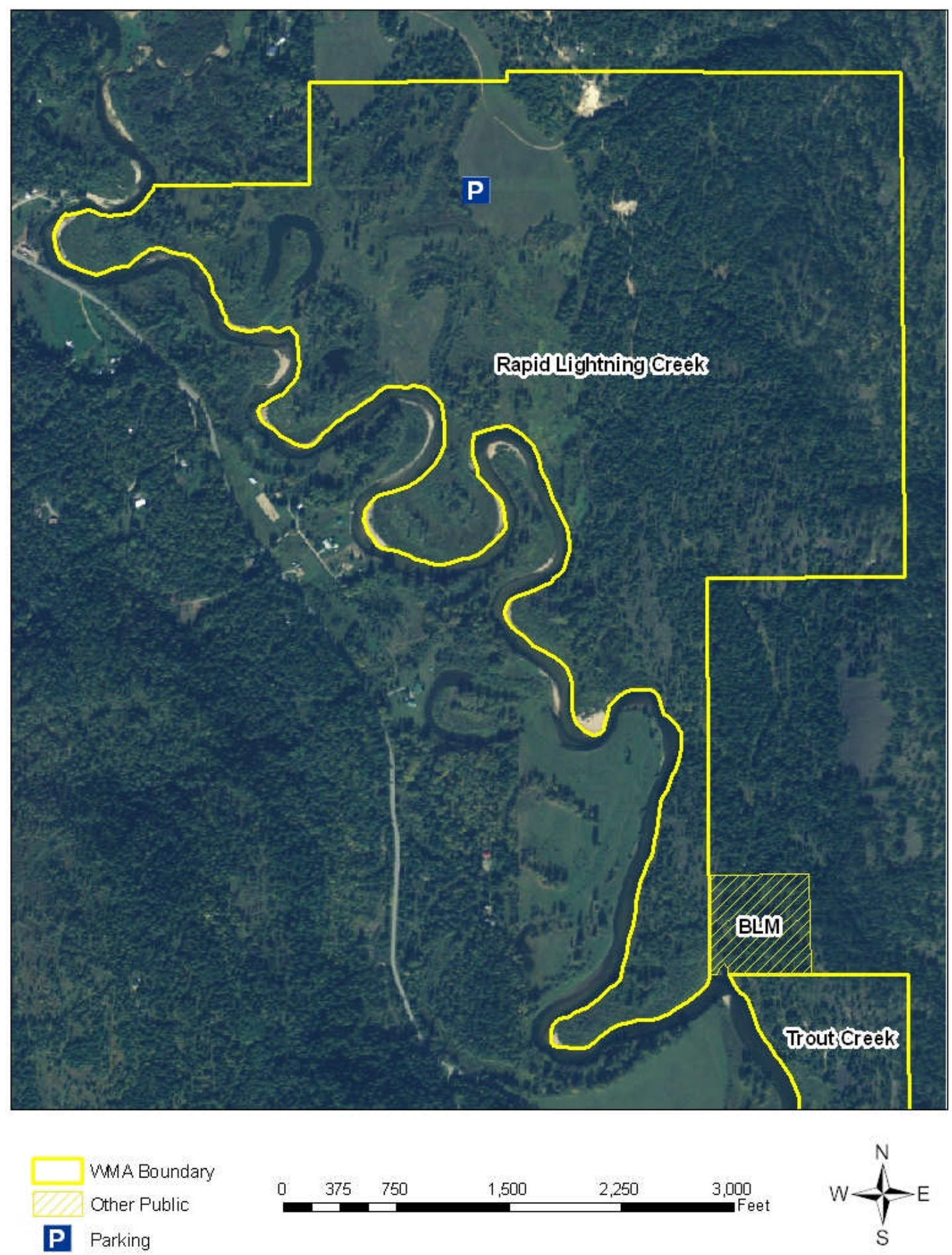
Figure 12. Idaho Department of Fish and Game: Trout Creek Habitat Segment. Pend Oreille Wildlife Management Area.
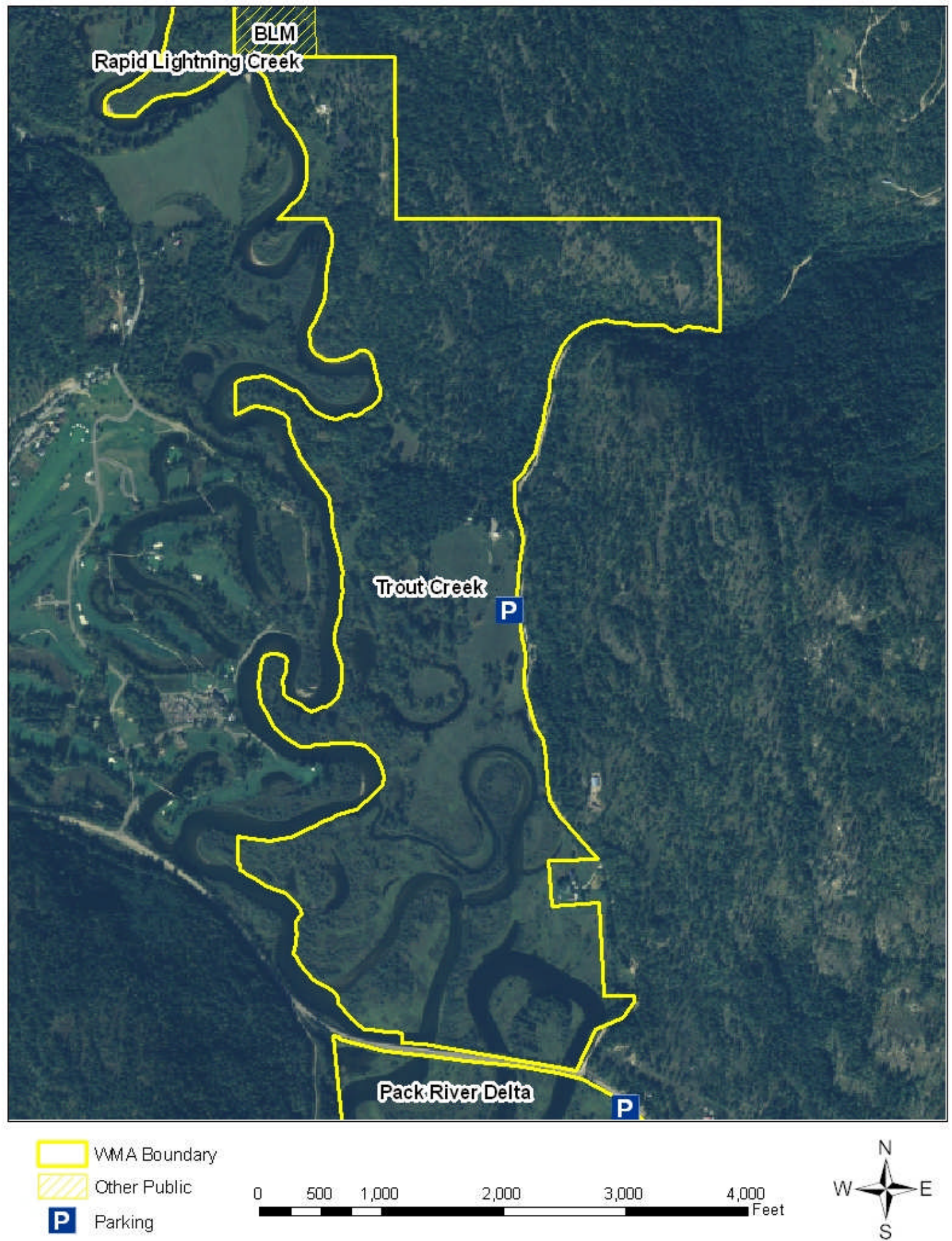
Figure 13. Idaho Department of Fish and Game: Westmond Lake Habitat Segment. Pend Oreille Wildlife Management Area.

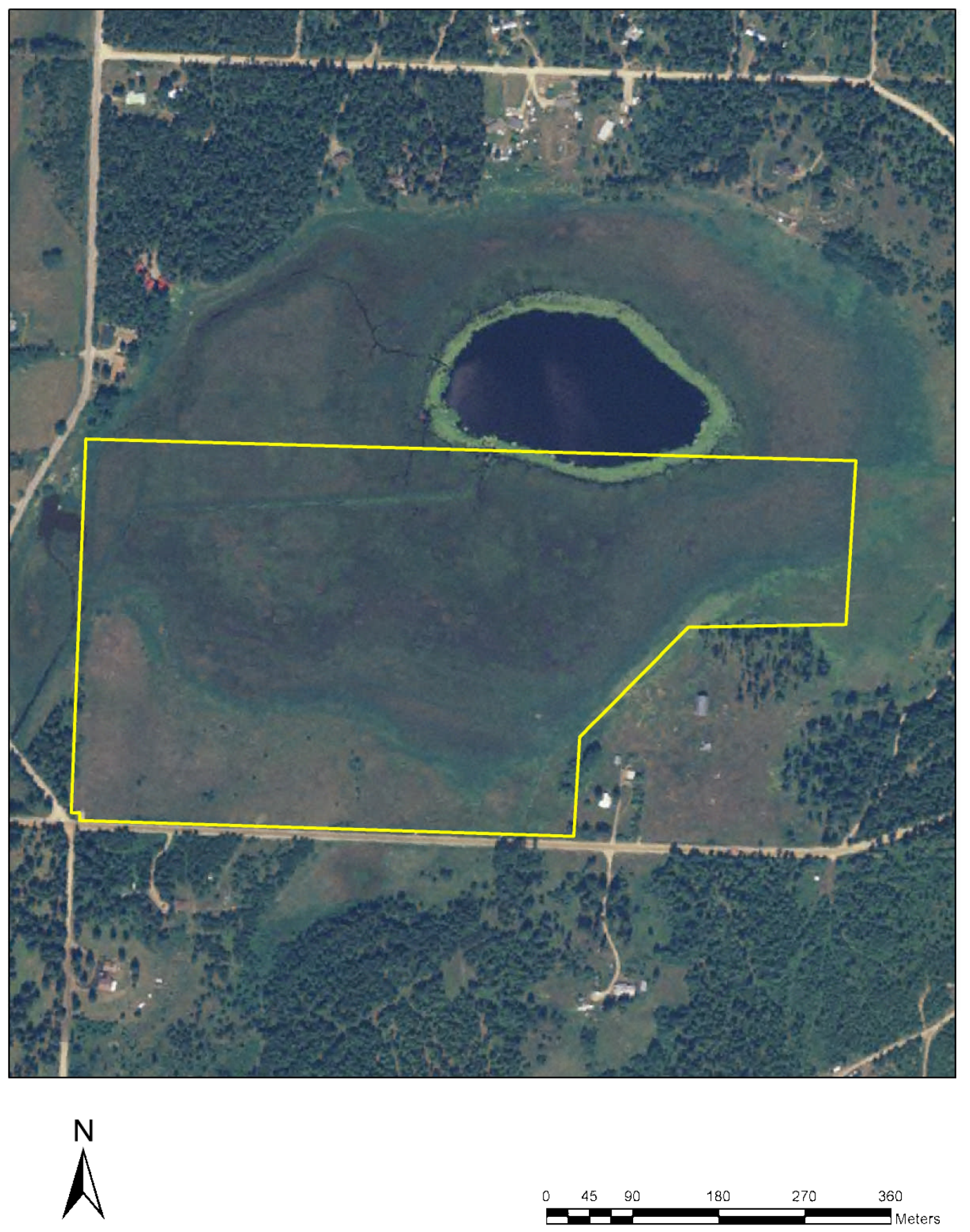


Figure 14. Idaho Department of Fish and Game: Lower St. Joe Habitat Segment. Coeur d'Alene Wildlife Management Area.

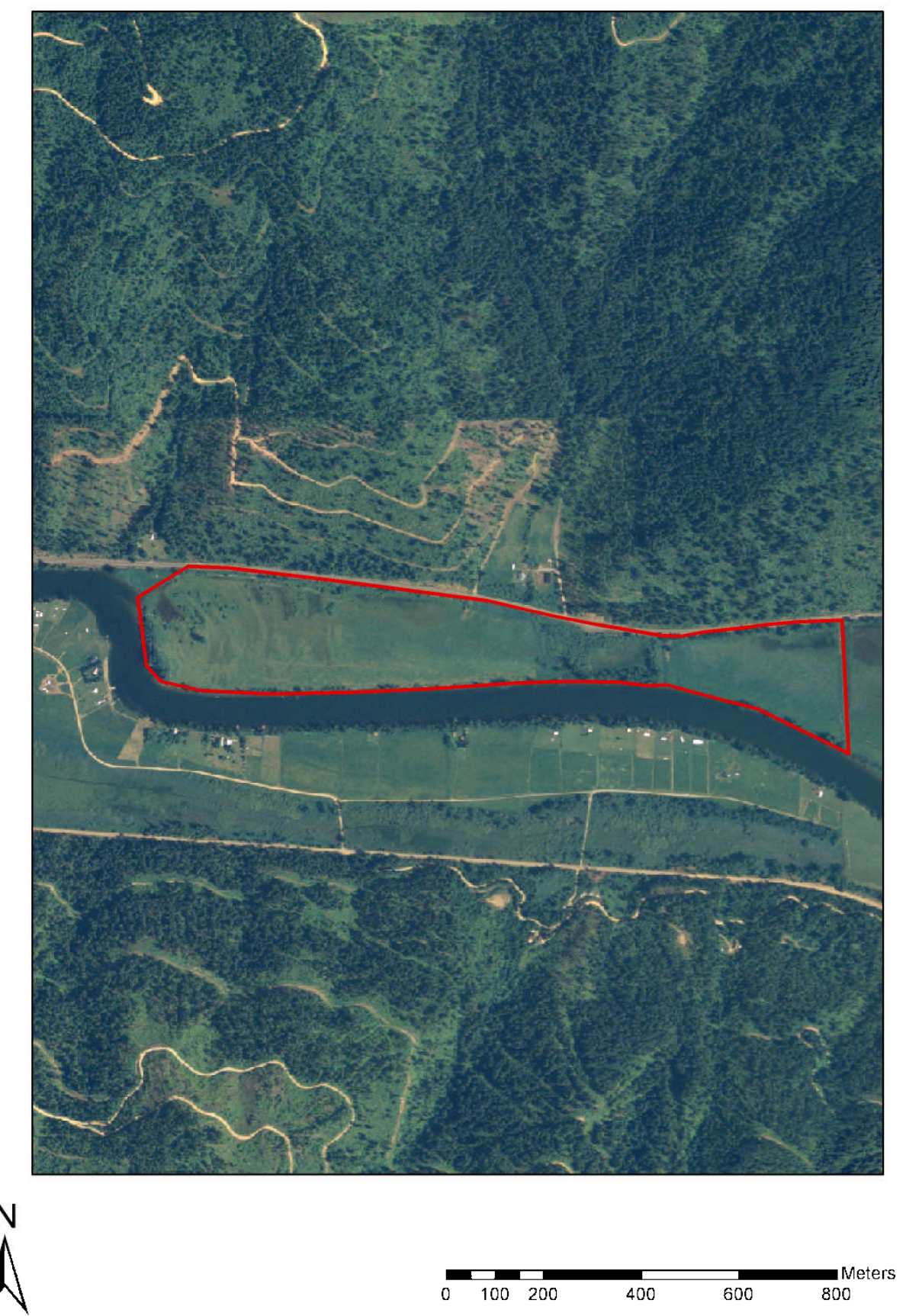

